\title{
РАЗРАБОТКА МЕТОДИКИ СИНТЕЗА АТОЗИБАНА И ДЕСМОПРЕССИНА ВЫСОКОЙ ЧИСТОТЫ ДЛЯ ПРОМЫШЛЕННОГО ПРОИЗВОДСТВА
}

\section{Д.В. Авдеев, М.В. Овчинников, А.С. Молокоедов, М.В. Сидорова}

ФГБУ «Национальный медицинский исследовательский центр кардиологии» Минздрава России, 121552, Россия, Москва, 3-я Черепковская, 15А.

В современном мире проблема преждевременных родов является частой при протекании беременности. Единственным лекарством для её предотвращения является препарат Атозибан («Трактоцил») - антагонист окситоциновых рецепторов.

Первичный ночной энурез распространён в основном среди детей до 5 лет (5-10\%), несахарный диабет, гемофиллия А и болезнь Виллебранда являются редкими заболеваниями, которые довольно сложно поддаются лечению. Для купирования этих болезней в основном применяется препарат Десмопрессин («Пресайнекс») - агонист второго типа вазопрессиновых рецепторов (V2).

Атозибан и Десмопрессин-дезаминоаналоги гипофизарных гормонов, состоящие из 9 аминокислотных остатков. Известны различные методы получения данных пептидов, но судя по литературным данным, предпочтение отдаётся синтезу в растворе. Нами был проведён синтез этих пептидов полностью на полимерном носителе, включая стадию циклизации. Так как Атозибан и Десмопрессин являются циклическими дисульфидами, именно стадия циклизации является основополагающей. Замыканиевнутримолекулярного S-S мостика на полимере помогло нам обойти проблему высоких разбавлений, необходимых при окислении в растворе, и сократить образование побочных продуктов, а также упростить процедуру выделения целевых соединений. Так как данные пептиды не содержат в своей структуре остатков триптофана в качестве окислителя мы выбрали $J_{2}$, поскольку он хорошо растворим в органических растворителях, обеспечивающих хорошую сольватацию пептидиллполимера, и при его использовании наблюдается прямая конверсия цистеин-защищённого пептида в циклический дисульфид. Проводя циклизацию, мы изучили влияние различных избытков $J_{2}$ на чистоту целевого дисульфида и подобрали оптимальные условия. Разработанная нами методика позволяет получить технический Атозибан чистотой 91,97\% и Десмопрессин чистотой 96,94\%. Образование димерных продуктов в обоих случаяхбыло менее 1\%, что открывает возможности внедрения этой методики в промышленное производство.

Работа выполнена при финансовой поддержке $3 A O$ «Обнинская химико-фармацевтическая компания». 